\title{
Tillage and cropping intensification effects on soil aggregation: Temporal dynamics and controlling factors under semiarid conditions
}

\author{
J. Álvaro-Fuentes, J.L. Arrúe, R. Gracia and M.V. López \\ Departamento de Suelo y Agua, Estación Experimental de Aula Dei, Consejo Superior de \\ Investigaciones Científicas (CSIC), POB 202, 50080-Zaragoza, Spain
}

\begin{abstract}
During decades, in semiarid agroecosystems of the Ebro valley, intensive soil tillage and low crop residue input has led to a loss of soil structure. Conservation tillage and cropping intensification can improve soil structure in these areas. The objective of this study was to determine the influence of three different tillage systems (conventional tillage, CT; reduced tillage, RT; and no-tillage, NT) under two cropping systems (barley-fallow rotation, CF; and continuous barley, $\mathrm{CC}$ ) on soil aggregation dynamics during two consecutive growing seasons (2003-2004 and 2004-2005). At the same time, the role that different soil and climatic factors play on soil aggregation in these semiarid areas was studied. Soil samples were collected at the soil surface $(0-5 \mathrm{~cm}$ depth) from a long-term tillage experiment with a loamy soil (Xerollic Calciorthid). Two aggregation indexes were studied: dry aggregate size distribution and water aggregate stability from both air-dried and field-moist macroaggregates. A decrease in tillage intensity resulted in a higher mean size of dry aggregates and a greater water aggregate stability in both cropping systems particularly under NT. During the whole experiment, the dry aggregate size distribution (measured as the mean weight diameter, MWD) and the water stability of field-moist and air-dried soil aggregates $\left(W A S_{A D}\right.$ and $W A S_{F M}$, respectively) were greater under NT than under RT and CT due to a higher soil organic matter content under NT. Intensification of cropping system resulted in a greater water aggregate stability (both WAS ${ }_{A D}$ and $W A S_{F M}$ ) but it did not have any effect in the MWD. Differences among tillage treatments
\end{abstract}


were more pronounced under the CC system than under the CF rotation due to the lower soil organic matter content and microbial biomass when long-fallowing was used. Variations in soil aggregation dynamics during the cropping season were mainly affected by crop growth and the associated activity of soil microorganisms. These findings indicate that the use of alternative management practices as NT and CC are viable strategies to improve soil aggregation from semiarid Ebro valley.

Keywords: Tillage; Water aggregate stability; Mean weight diameter; Semiarid agroecosystems 


\section{Introduction}

In agroecosystems, soil aggregation influences a large number of physical and biogeochemical processes such as soil organic matter (SOM) protection, root density and elongation, soil erosion, oxygen diffusion, soil water retention and dynamics, nutrient adsorption and microbial community structure ([Amézketa, 1999] and [Six et al., 2004]). In Mediterranean Ebro valley, where water is the most limiting factor affecting crop production (Angás et al., 2006), there is a high potential risk of land degradation. Consequently, in Mediterranean agroecosystems soil aggregation plays an important role in the maintenance of soil quality and, thus, crop productivity.

Soil tillage and, particularly, mouldboard ploughing, accelerates SOM decomposition ([Bruce et al., 1999] and [Paustian et al., 2000]) and decreases dry soil aggregation ([Yang and Wander, 1998] and [Mrabet et al., 2001]) and aggregate stability to water immersion ([Singh et al., 1994] and [Hernanz et al., 2002]). Tillage has a direct effect on soil structure through the mechanical breakage of large clods and macroaggregates. At the same time, the surface of tilled soils is more exposed to the action of climatic factors and, especially, to water and wind erosion processes ([Balesdent et al., 2000] and [López et al., 2000]). Also, tillage has an indirect effect on soil structure due to its influence on SOM. The relationship between SOM and soil structure has been widely studied in the literature ([Tisdall and Oades, 1982], [Puget et al., 1995] and [Six et al., 2002]). Organic matter acts as a binding agent for aggregate formation ([Amézketa, 1999] and [Bronick and Lal, 2005]). Tisdall and Oades (1982) classified organic binging agents as a function of their persistence and relation with soil aggregates in three groups: transient (e.g., polysaccharides), temporary (e.g., roots and hyphae) and persistent (e.g., aromatic humic material). Oades (1984) suggested that soil macroaggregate stability to water immersion is related with organic materials (e.g. roots, hyphae, worm casts ...).

The type of cropping system also influences soil aggregation. Several authors, studying the effect of different cropping systems on aggregation, have observed significant positive relationship between aggregate stability and C inputs ([Shaver et al., 2002] and [Kong et al., 2005]). The inclusion of fallowing in the rotation has an adverse effect on soil aggregation due to the lack of $C$ inputs. However, under Mediterranean semiarid conditions, changes induced by cropping systems are expected to be low due to the limited $C$ inputs under these conditions (Masri and Ryan, 2006). 
Temporal changes in soil aggregation during crop growth have been studied by several authors. Perfect et al. (1990) studying the effect of different factors on water aggregate stability (WAS) during a cropping season, concluded that the gravimetric soil water content at sampling was the soil factor that mostly influenced WAS. Similar findings were reported by Angers (1992) and Chan et al. (1994). However, these authors did not find any relationship between WAS during the season and total soil organic carbon (SOC) (Chan et al., 1994) and microbial biomass (Perfect et al., 1990).

In studies on the temporal variation on soil aggregation, WAS analyses have been made on air-dried aggregates (Yang and Wander, 1998), field-moist aggregates ([Perfect et al., 1990] and [Angers, 1992]) and both air-dried and field-moist aggregates (Chan et al., 1994). The study of the temporal variations on WAS with field-moist aggregates gives a realistic approach of the influence of the aggregate water content on WAS. However, air-dried aggregates for WAS analyses give an interesting indication of the susceptibility of the aggregates to slaking (Haynes and Swift, 1990). In semiarid Mediterranean conditions, where low soil water content together with erratic rainfall events are two main characteristics, it is worth using air-dried and field-moist aggregates for the study of temporal variations of WAS because air-dried aggregates inform about the potential resistance of aggregates to rapid wetting due to an intensive rainfall after a drought period.

In semiarid agroecosystems of the Ebro river valley, the cereal-fallow rotation together with intensive soil tillage, including mouldboard ploughing, are widespread agricultural management practices. In these agroecosystems, crop yield is limited by the continuous use of these practices during decades and the low and erratic rainfall ([López et al., 1996], [Lampurlanés et al., 2002] and [Moret et al., 2006]). Moreover, these practices and limited biomass production have led to low SOM contents (Álvaro-Fuentes et al., 2008) and weak soil structure thus negatively affecting soil quality. Therefore, in these agroecosystems, it is necessary a shift from traditional agriculture towards a more conservative agriculture with lower soil tillage intensity and with the suppression of long-fallowing.

Several studies have been carried out in semiarid Mediterranean agroecosystems to study the effects of conservation tillage, especially no-tillage (NT), and cropping systems intensification on soil aggregation ([López et al., 2000], [Mrabet et al., 2001], [Hernanz et al., 2002] and [Masri and Ryan, 2006]). However, in these studies no attempts were made to study the temporal changes of soil aggregation during the crop growth. 
The objectives of this study were to (i) evaluate the effect of conservation tillage systems (reduced tillage and no-tillage) and the intensification of cropping systems on dry aggregate distribution and wet aggregate stability, (ii) study temporal changes on soil surface aggregation during the growing season and (iii) to identify the main soil properties contributing to soil aggregation.

\section{Materials and methods}

\subsection{Site, tillage and cropping systems}

The study was conducted from February 2004 to September 2005 at the dryland research farm of the Estación Experimental de Aula Dei (Consejo Superior de Investigaciones Científicas) in the Zaragoza province $\left(41^{\circ} 44^{\prime} 30^{\prime \prime} \mathrm{N}, 0^{\circ} 46^{\prime} 18^{\prime \prime} \mathrm{W}, 270 \mathrm{~m}\right)$. Details on the experimental site and soil are given in Table 1 and precipitation and maximum and minimum temperatures recorded at the experimental site for each year of the study are presented in Table 2. In the study site, a long-term tillage and cropping systems comparison experiment was established in 1989 with three tillage treatments: conventional tillage (CT), reduced tillage (RT) and no-tillage (NT) under both the traditional cereal-fallow rotation (CF) and the continuous cropping (CC) system with barley (Hordeum vulgare, L.). In both cropping systems, the CT treatment consisted of a pass of mouldboard ploughing to a depth of $30-40 \mathrm{~cm}$. The RT treatment was implemented by chisel ploughing to a depth of $25-30 \mathrm{~cm}$. In both CT and RT, primary tillage was followed by a pass of a sweep cultivator (10-15 cm depth). In the NT treatment no-tillage operations were done and soil was kept free of weeds by spraying a total herbicide (glyphosate). In both cropping systems, mouldboard ploughing in the CT plots was followed by a pass with a tractormounted scrubber as a traditional practice to break down large clods. At the CC system, tillage was implemented every November before barley sowing. However, in the CF rotation, tillage was implemented in March, every two years, during the season in which barley was not sown.

The experiment design was a randomized complete block design with three replicates. Treatment plot size was $33.5 \mathrm{~m} \times 10 \mathrm{~m}$.

\subsection{Soil sampling}

Soil samples were collected on nine different dates from February 2004 to September 2005. Sampling dates and related cropping phases are shown in Table 3. For aggregate analyses, 
samples were collected with a flat spade from the $0-5 \mathrm{~cm}$ soil layer and placed in crushresistant, air-tight containers in order to avoid aggregate breakage during sample transportation to the laboratory. On each sampling date, four composite samples were collected from each plot. Once in the laboratory, two samples were stored at $4{ }^{\circ} \mathrm{C}$ and the other two samples were air-dried and stored at room temperature. In September 2005, a composite soil sample was taken from the $0-5 \mathrm{~cm}$ layer of each plot to measure the total soil organic carbon (SOC) content. In this case, the soil samples were air-dried, ground and sieved to $2 \mathrm{~mm}$. Extra composite soil samples from each plot were taken from March 2005 to September 2005 for the determination of microbial biomass $\mathrm{C}$.

\subsection{Soil aggregation measurements}

Soil aggregation was characterized by the dry aggregate size distribution and water aggregate stability. The dry aggregate size distribution was measured by placing $200 \mathrm{~g}$ of air-dried soil (previously passed through a $8 \mathrm{~mm}$ sieve) on the top of a vertical electromagnetic sieve apparatus (FRITSCH Analysette $3 \mathrm{PRO}$ ) equipped with a stack of seven sieves with the following screens: $4,2,1,0.85,0.5,0.25$ and $0.05 \mathrm{~mm}$. In order to determine the optimum combination of sieving time and amplitude (vertical vibration height), a series of experiments testing different sieving times and amplitudes were carried out using different soils. A sieving time of $5 \mathrm{~min}$ and with amplitude of $0.1 \mathrm{~mm}$ were finally fixed for our experiment. Dry soil remaining on each sieve was collected and weighed. The mean weight diameter (MWD) of the soil aggregates (Youker and McGuiness, 1957) was used to express dry aggregate size distribution.

MWD $=\sum_{i=j}^{8} X_{i} W_{i}$

where $X_{i}$ is the mean diameter of the size fraction, and $W_{i}$ is the proportion of total sample weight retained on each sieve.

Dry aggregates between 1 and $2 \mathrm{~mm}$ were separated to determine the water aggregate stability $\left(W_{A} S_{A D}\right)$ and soil organic carbon $(S O C)$ for this aggregate size class. The WAS AD $_{\text {was }}$ measured using the procedure of Kemper and Rosenau (1986). Briefly, $4 \mathrm{~g}$ of 1-2 mm airdried aggregates were placed on the top of a $0.25 \mathrm{~mm}$ sieve and sieved in distilled water during $3 \mathrm{~min}$ with a stroke length of $1.3 \mathrm{~cm}$ and a frequency of 35 strokes $\mathrm{min}^{-1}$. Soil retained on each sieve was transferred to an aluminium pan and dried and weighed. Sand correction 
was made in all the samples by dispersing the stable aggregates with sodium hexametaphosphate and sieving again through a $0.25 \mathrm{~mm}$ sieve.

From the field-moist soil samples, 1-2 mm aggregates were separated with the same procedure described for the MWD determination. The same procedure for the air-dried aggregates was used to measure the water stability of the field-moist aggregates $\left(\mathrm{WAS}_{\mathrm{FM}}\right)$.

\subsection{Soil water content, SOC and microbial biomass}

The gravimetric soil water content was measured from each sample taken for field-moist WAS measurements, by oven drying a subsample at $105^{\circ} \mathrm{C}$. The total SOC content and the SOC content of the 1-2 mm aggregate size class was measured using the wet oxidation method of Walkley and Black (Nelson and Sommers, 1982). The microbial biomass C was measured using the chloroform-fumigation and direct extraction method (Vance et al., 1987).

Daily precipitation and air temperature data were collected over the entire experimental period using an automatic weather station (Campbell Scientific Inc., datalogger CR10) located within the experimental field.

\subsection{Statistical analyses}

Statistical analyses of data were performed using the SAS (SAS Institute, 1990). Analyses of variance (ANOVA) were applied to compare tillage treatment. Differences between means were tested with Duncan's multiple range test. Regression analyses were used to determine the relationships between aggregation indexes and SOC, microbial biomass $\mathrm{C}$ and gravimetric soil water content.

\section{Results and discussion}

\subsection{Tillage and cropping system effects}

\subsubsection{Dry aggregate size distribution}

Dry aggregate size distribution was measured and represented as the mean weight diameter (MWD) of soil aggregates. On average, in the CC system, the greatest mean MWD (2.85 $\mathrm{mm})$ was measured in NT followed by CT with $2.31 \mathrm{~mm}$ and RT with $2.20 \mathrm{~mm}$ (Table 4). In the CF rotation, the greatest mean MWD was also observed under NT $(2.97 \mathrm{~mm})$ but, in contrast to 
the CC system, followed by RT and CT with 2.39 and 2.28, respectively (Table 4). Similar studies have also observed greater MWD for dry aggregates in NT compared with tilled treatments ([Unger and Fulton, 1990], [Singh et al., 1994], [Yang and Wander, 1998] and [Eynard et al., 2004]). Yang and Wander (1998) concluded that the aggregate size increases with the SOC content. In our study, total SOC was greatest under NT (Table 5 $)$ and showed a marked degree of correlation with mean MWD $\left(R^{2}=0.400 ; P<0.01\right)$ (Table 6). Furthermore, it was also found a positive linear relationship between MWD and organic carbon content of the 1-2 mm aggregates (Table 6). Shaver et al. (2003), under semiarid conditions, observed that the macroaggregate content was closely related with the organic carbon of the macroaggregates.

Differences in mean MWD among tillage treatments resulted from a different proportion of aggregates among size classes. Thus, the greatest mean MWD value observed in NT was mainly due to a significantly higher proportion of large macroaggregates (> $4 \mathrm{~mm}$ and $2-4 \mathrm{~mm}$ ) in this treatment compared with CT and RT (Fig. 1). On the contrary, the proportion of aggregates within the $0.5-0.84$ and $0.25-0.5 \mathrm{~mm}$ size classes were significantly lower under NT than under CT and RT (Fig. 1). In addition to mechanical breakage of aggregates by tillage operations, in RT and, especially, in CT, insufficient residue cover on the soil surface does not protect the integrity of soil aggregates against raindrop impact or abrasive winds during erosive episodes ([Saber and Mrabet, 2002] and [López et al., 2003]).

A slightly greater mean MWD was measured in the CF rotation compared with the CC system. Other similar studies under Mediterranean semiarid conditions have also observed lower dry aggregation in cereal monocultures compared with cereal-fallow rotations ([Mrabet et al., 2001] and [Masri and Ryan, 2006]).

\subsubsection{Water stability of air-dried aggregates $\left(W_{A} S_{A D}\right)$}

Slaking defined as the rupture and disintegration of dry aggregates due to a fast wetting at atmospheric pressure (Kemper and Rosenau, 1986) led to a breakage of 1-2 mm aggregates in the three tillage treatments. This effect was especially significant in CT and RT (Table 4 ). In

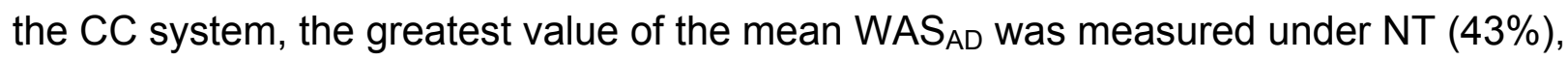
followed by RT (21\%) and CT (16\%) (Table 4). Likewise, in the CF rotation, the greatest mean WAS $_{A D}$ was also observed under NT (18\%), followed in this case by CT (15\%) and RT (12\%) (Table 4). These results are in agreement with other studies in which a greater water stability was found in aggregates from NT compared with aggregates from other tilled systems ([Carter, 1992], [Smettem et al., 1992], [Cambardella and Elliot, 1993], [Franzluebbers and Arshad, 
1996], [Six et al., 1998] and [Eynard et al., 2004]). In our study, the greater mean WAS under NT was related with a greater total $\mathrm{SOC}$, microbial biomass $\mathrm{C}$ and $1-2 \mathrm{~mm}$ aggregate $\mathrm{C}$ (Table $\underline{5}$ and $\underline{\text { Table } 6}$ ). It is well established that SOC increases the water stability of the aggregates ([Haynes and Swift, 1990] and [Hernanz et al., 2002]) due to a greater cohesion of soil mineral particles and to an increase of aggregate hydrophobicity (Chenu et al., 2000).

In relation with the intensification of the cropping system, a greater mean value of WAS ${ }_{A D}$ was observed under the CC system than under the CF rotation (Table 4). The suppression of long-

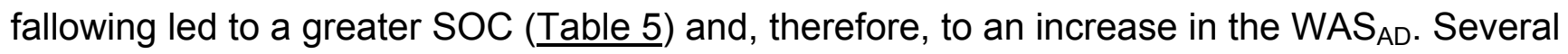
studies have observed greater WAS $_{\mathrm{AD}}$ when fallow is removed from the cropping system ([Saber and Mrabet, 2002] and [Shaver et al., 2002]). The later authors, comparing three notillage cropping systems with different cropping intensity in semiarid Great Plains of the USA, concluded that greater cropping intensification leads to a greater water aggregate stability.

\subsubsection{Water aggregate stability of field-moist aggregates $\left(\mathrm{WAS}_{\mathrm{FM}}\right)$}

As observed for the air-dried aggregates, the mean $\mathrm{WAS}_{\mathrm{FM}}$ was greater under NT than under CT and RT in both cropping systems (Table 4). In the CC system, more than $40 \%$ of the $1-$ $2 \mathrm{~mm}$ aggregates were stables to water immersion, whereas in RT and CT this stability decreased to $21 \%$ and $16 \%$, respectively (Table 4). In the CF system, $27 \%$ of NT field-moist aggregates were stable, whereas in RT and CT the mean WAS $\mathrm{FM}_{\mathrm{FM}}$ decreased to $20 \%$ and $18 \%$, respectively (Table 4). Angers et al. (1993), working with field-moist aggregates from different tillage systems, also found the greatest aggregate stability under NT than under other tilled systems.

Chan et al. (1994) found lower water stability in air-dried aggregates than in field-moist aggregates. They suggested that in field-moist aggregates slaking does not occur, being the aggregate breakdown due to the mechanical disturbance of the sieving action. In our study, in the $\mathrm{CC}$ system, the mean values of $\mathrm{WAS}_{\mathrm{AD}}$ and $\mathrm{WAS}_{\mathrm{FM}}$ were similar. In the CF rotation, a slightly greater mean water aggregate stability was measured for field-moist aggregates than for air-dried aggregates. We suggest that in plots with high SOC content (e.g., NT in the CC system) differences between $\mathrm{WAS}_{\mathrm{FM}}$ and WAS $\mathrm{WD}_{\mathrm{AD}}$ were minimum since soil mineral particles were strongly bounded and aggregates had a high degree of hydrophobicity (Haynes and Swift, 1990).

As observed with the WAS $\mathrm{SD}_{\mathrm{AD}}$, the $\mathrm{WAS}_{\mathrm{FM}}$ had a strong relationship with the total SOC, microbial biomass $C$ and $1-2 \mathrm{~mm}$ aggregate $C$ (Table 6). 


\subsection{Temporal variation in soil aggregation}

\subsubsection{Temporal variation of the aggregate mean weight diameter (MWD)}

The temporal variation of the MWD is shown in Fig. 2. In both the CC and CF cropping systems, the lowest MWD was observed under RT in September 2004 and the greatest values in May 2004. Yang and Wander (1998), studying variations in MWD over a growing season in a corn-soybean rotation, concluded that temporal variation in dry aggregate size was affected by several interacting factors, such as soil moisture and tillage and cropping practices. In our study, however, the relationship found between soil moisture at the time of sampling and MWD was low and not significant (able 6 ). The low relationship found does not imply the effects of rainfall together with tillage on soil surface conditions and thus on MWD. In the Mediterranean semiarid areas, with low residues placed over soil surface soil crusting effects have an especial significance (Lampurlanés and Cantero-Martínez, 2006). We hypothesized that soil crusting processes due to rain impact might be more significant under the two tilled treatments (CT and RT) were soil surface kept free of crop residues. Consequently, this crusting processes led to a lower MWD under the CT and RT treatments compared with the NT treatment were greater amount of crop residues were kept on soil surface protecting from soil crusting.

At the same time, plant development, specifically root growth, promotes soil aggregation due to the release of organic compounds in two different ways: by binding soil particles together and by stimulating soil microorganisms activity ([Angers and Caron, 1998] and [Six et al., 2004]). In our study, more precipitation was measured in the 2004 cropping season than in the 2005 season. From February to April 2004 was measured $141.8 \mathrm{~mm}$ of precipitation meanwhile during the same period in 2005 only $29.8 \mathrm{~mm}$ (Table 2). Consequently, MWD peak observed in May 2004 (Fig. 2) might be explained by the greater root development due to the greater crop development.

\subsubsection{Temporal variation in water stability of air-dried aggregates (WAS $S_{A D}$ )}

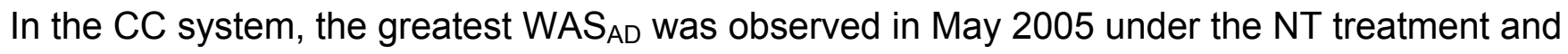

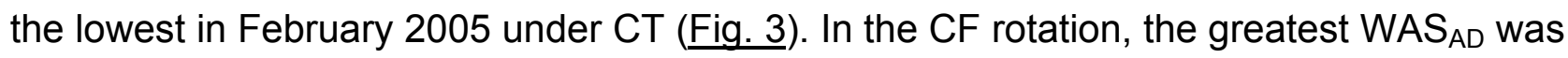
measured in September 2004 under NT and the lowest in September 2005 under CT.

In both cropping systems, there was measured an increase in WAS $\mathrm{AD}_{\mathrm{D}}$ during the crop growth period (March-May) (Fig. 3), as it was observed in the MWD. However, during the fallow

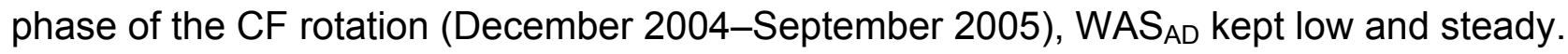


Crop growth could have increased aggregate stability through the following mechanisms: (a) physical enmeshment of fine particles into stable macroaggregates due to root growth (Amézketa, 1999); (b) root release of soluble organic exudates that increased aggregate water stability (Traoré et al., 2000); (c) simultaneous stimulation of microbial activity by these root secretions, which promoted the entrapment of soil particles by microbial hyphae (Oades and Waters, 1991). In our study, microbial biomass appeared to be a main factor affecting water stability of aggregates due to the significant linear relationship $(P<0.001)$ found between WAS $_{\mathrm{AD}}$ and microbial biomass $\mathrm{C}$ (Table 6 ).

The lack of root activity during the fallow phase of the CF system, resulted in a loss of water stable aggregates in all the tillage treatments (Fig. 3). Oades (1984) concluded that fallowing practice was the most harmful management practice for soil structure because the proportion of water stable macroaggregates declines due to the absence of an active root system.

Regarding soil water content at the time of sampling as a soil factor affecting WAS $\mathrm{AD}_{\mathrm{D}}$, Perfect et al. (1990) concluded that this factor mainly explains the temporal variation in WAS $\mathrm{AD}_{\mathrm{A}}$ They

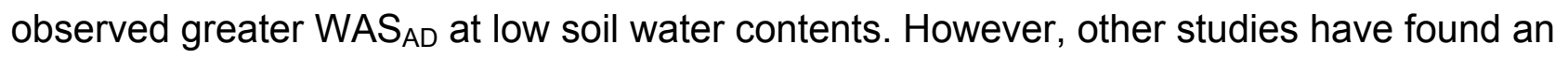

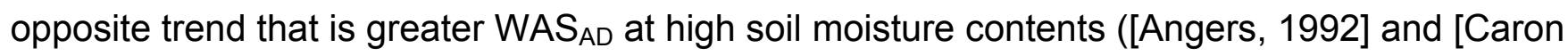

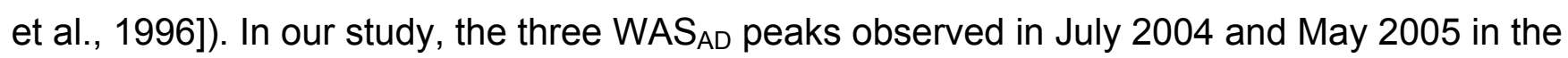
CC system and in September 2004 in the CF rotation (Fig. 3) were coincident with the highest values of soil moisture (Fig. 4). However, when regression analyses between WAS FD $_{\text {f }}$ and soil moisture were performed for the whole study period a low and a not significant relationship was obtained (Table 6). Therefore, in our conditions soil water content at sampling had a low effect on the water stability of air-dried aggregates.

\subsubsection{Temporal variation in water stability of field-moist aggregates $\left(\mathrm{WAS}_{\mathrm{FM}}\right)$}

The water stability of field-moist aggregates $\left(\mathrm{WAS}_{\mathrm{FM}}\right)$ followed a similar trend than that found for the water stability of air-dried aggregates $\left(W_{A D}\right)$ and showed high values during crop growth especially under NT (Fig. 5).

It is worth mentioning that from February 2004 to May 2004 there was a marked increase in WAS $_{\mathrm{FM}}$ (Fig. 5). This increase was, however, more gradual than that observed for air-dried aggregates (ig. 3) . Different aggregate water content and, consequently, different behaviour against the slaking process (Chan et al., 1994) could explain this difference in water stability between field-moist and air-dried soil aggregates. As it was observed for WAS $\mathrm{AD}_{\mathrm{A}}$, regression 
analyses between soil water content at sampling and WAS $\mathrm{FM}_{\mathrm{FM}}$ was low and not significant (Table 6).

\section{Conclusions}

A decrease in tillage intensity improved soil aggregation. Greater soil organic carbon (SOC) content and microbial biomass under no-tillage led to an increase in the mean weight diameter (MWD) and water stability of soil aggregates as compared to reduced tillage (chisel ploughing) and conventional tillage (mouldboard ploughing). During the period of vegetative growth of barley crop under continuous cropping and crop-fallow rotation aggregate stability increased due to the effect of root development and soil microorganism activity in the formation and stabilization of soil aggregates. Long-fallowing in the barley-fallow rotation led to a decrease in the water stability of soil aggregates although the aggregate size was not affected. Lower SOC content and microbial activity reduced the amount of stable aggregates in that rotation.

Soils in the semiarid Mediterranean agroecosystems are characterized by a low soil organic matter content and a weak soil structure. In this study, we have demonstrated that the use of no-tillage and the suppression of long-fallowing may lead to an increase in soil aggregation and structural stability in these agroecosystems. In semiarid regions, where rainfall and consequently soil water content is the most limiting factor for crop production, an improvement in aggregate stability and soil structure may lead to better water infiltration and retention in the soil profile and ultimately to better crop yields.

\section{Acknowledgements}

The field and laboratory assistance of Sofía Alcrudo, Beatriz Silva and María Josefa Salvador is gratefully acknowledged. This research was supported by the Comisión Interministerial de Ciencia y Tecnología of Spain (Grants AGL2001-2238-CO2-01, AGL2004-07763-C02-02 and AGL2007-66320-CO2-02/AGR) and the European Union (FEDER funds). The first author was awarded a FPI fellowship by the Spanish Ministry of Science and Education. 


\section{References}

Álvaro-Fuentes et al., 2008 J. Álvaro-Fuentes, M.V. López, C. Cantero-Martínez and J.L. Arrúe, Tillage effects on soil organic carbon fractions in Mediterranean dryland agroecosystems, Soil Sci. Soc. Am. J. 72 (2008), pp. 541-547.

Amézketa, 1999 E. Amézketa, Soil aggregate stability: a review, J. Sustain. Agric. 14 (1999), pp. 83151.

Angás et al., 2006 P. Angás, J. Lampurlanés and C. Cantero-Martínez, Tillage and N fertilization effects on N dynamics and barley yield under semiarid Mediterranean conditions, Soil Tillage Res. 87 (2006), pp. 59-71.

Angers, 1992 D.A. Angers, Changes in soil aggregation and organic carbon under corn and alfalfa, Soil Sci. Soc. Am. J. 56 (1992), pp. 1244-1249.

Angers and Caron, 1998 D.A. Angers and J. Caron, Plant-induced changes in soil structure: processes and feedbacks, Biogeochemistry 42 (1998), pp. 55-72

Angers et al., 1993 D.A. Angers, N. Samson and A. Légère, Early changes in water-stable aggregation induced by rotation and tillage in a soil under barley production, Can. J. Soil Sci. 73 (1993), pp. 51-59. Balesdent et al., 2000 J. Balesdent, C. Chenu and M. Balabane, Relationship of soil organic matter dynamics to physical protection and tillage, Soil Tillage Res. 53 (2000), pp. 215-230.

Bronick and Lal, 2005 C.J. Bronick and R. Lal, Soil structure and management: a review, Geoderma 124 (2005), pp. 3-22.

Bruce et al., 1999 J.P. Bruce, M. Frome, E. Haites, H. Janzen, R. Lal and K. Paustian, C sequestration in soils, J. Soil Water Conserv. 54 (1999), pp. 382-389.

Cambardella and Elliot, 1993 C.A. Cambardella and E.T. Elliot, Carbon and nitrogen distribution in aggregates from cultivated and native grassland soils, Soil Sci. Soc. Am. J. 57 (1993), pp. 1071-1076.

Caron et al., 1996 J. Caron, C.R. Espindola and D.A. Angers, Soil structural stability during rapid wetting: influence of land use on some aggregate properties, Soil Sci. Soc. Am. J. 60 (1996), pp. 901908.

Carter, 1992 M.R. Carter, Influence of reduced tillage systems on organic matter, microbial biomass, macro-aggregate distribution and structural stability of the surface soil in a humid climate, Soil Tillage Res. 23 (1992), pp. 361-372.

Chan et al., 1994 K.Y. Chan, D.P. Heenan and R. Ashley, Seasonal changes in surface aggregate stability under different tillage and crops, Soil Tillage Res. 28 (1994), pp. 301-314.

Chenu et al., 2000 C. Chenu, Y. Le Bissonais and D. Arrouays, Organic matter influence on clay wettability and soil aggregate stability, Soil Sci. Soc. Am. J. 64 (2000), pp. 1479-1486. 
Eynard et al., 2004 A. Eynard, T.E. Schumacher, M.J. Lindstrom and D.D. Malo, Aggregate sizes and stability in cultivated South Dakota prairie Ustolls and Usterts, Soil Sci. Soc. Am. J. 68 (2004), pp. 1360-1365.

Franzluebbers and Arshad, 1996 A.J. Franzluebbers and M.A. Arshad, Water-stable aggregation and organic matter in four soils under conventional and zero tillage, Can. J. Soil Sci. 76 (1996), pp. 387393.

Haynes and Swift, 1990 R.J. Haynes and R.S. Swift, Stability of soil aggregates in relation to organic constituents and soil water content, J. Soil Sci. 41 (1990), pp. 73-83.

Hernanz et al., 2002 J.L. Hernanz, R. López, L. Navarrete and V. Sánchez-Girón, Long-term effects of tillage systems and rotations on soil structural stability and organic carbon stratification in semiarid central Spain, Soil Tillage Res. 66 (2002), pp. 129-141.

Kemper and Rosenau, 1986 W.D. Kemper and R.C. Rosenau, Aggregate stability and size distribution. In: A. Klute, Editor, Methods of Soil Analysis. Part 1. Physical and Mineralogical Methods. ASA Book Series No. 9 Agronomy (1986), pp. 425-442 Madison, WI, USA.

Kong et al., 2005 A.Y.Y. Kong, J. Six, D.C. Bryant, R.F. Denison and C. Van Kessel, The relationship between carbon input, aggregation, and soil organic carbon stabilization in sustainable cropping systems, Soil Sci. Soc. Am. J. 69 (2005), pp. 1078-1085.

Lampurlanés and Cantero-Martínez, 2006 J. Lampurlanés and C. Cantero-Martínez, Hydraulic conductivity, residue cover and soil roughness under different tillage systems in semiarid conditions, Soil Tillage Res. 85 (2006), pp. 13-26

Lampurlanés et al., 2002 J. Lampurlanés, P. Angás and C. Cantero-Martínez, Tillage effects on water storage during fallow and on barley root growth and yield in two contrasting soils in the semiarid Segarra region in Spain, Soil Tillage Res. 65 (2002), pp. 207-220.

López et al., 1996 M.V. López, J.L. Arrúe and V. Sánchez-Girón, A comparison between seasonal changes in soil water storage and penetration resistance under conventional and conservation tillage systems in Aragón, Soil Tillage Res. 37 (1996), pp. 251-271.

López et al., 1998 M.V. López, M. Sabre, R. Gracia, J.L. Arrúe and L. Gomes, Tillage effects on soil surface conditions and dust emissions by wind erosion in semiarid Aragón (NE Spain), Soil Tillage Res. 45 (1998), pp. 91-105.

López et al., 2000 M.V. López, R. Gracia and J.L. Arrúe, Effects of tillage on soil surface properties affecting wind erosion in semiarid fallow lands of Central Aragón, Eur. J. Agron. 12 (2000), pp. 191-199 López et al., 2003 M.V. López, D. Moret, R. Gracia and J.L. Arrúe, Tillage effects on barley residue cover during fallow in semiarid Aragon, Soil Tillage Res. 72 (2003), pp. 53-64. 
Masri and Ryan, 2006 Z. Masri and J. Ryan, Soil organic matter and related physical properties in a Mediterranean wheat-based rotation trial, Soil Tillage Res. 87 (2006), pp. 146-154.

Moret et al., 2006 D. Moret, J.L. Arrúe, M.V. López and R. Gracia, Influence of fallowing practices on soil water and precipitation storage efficiency in semiarid Aragon (NE Spain), Agric. Water Manag. 82 (2006), pp. 161-176.

Mrabet et al., 2001 R. Mrabet, N. Saber, A. El-Brahli, S. Lahlou and F. Bessam, Total, particulate organic matter and structural stability of a Calcixeroll soil under different wheat rotations and tillage systems in a semiarid area of Morocco, Soil Tillage Res. 57 (2001), pp. 225-235.

Nelson and Sommers, 1982 D.W. Nelson and L.E. Sommers, Total carbon, organic carbon and organic matter. In: A.L. Page et al., Editors, Methods of Soil Analysis, Part 2, 2nd Edition Agronomy vol. 9, Soil Science Society of America, Madison, WI, USA (1982), pp. 539-579.

Oades, 1984 J.M. Oades, Soil organic matter and structural stability: mechanisms and implications for management, Plant Soil 76 (1984), pp. 319-337.

Oades and Waters, 1991 J.M. Oades and A.G. Waters, Aggregate hierarchy in soils, Aust. J. Soil Res. 29 (1991), pp. 815-828.

Paustian et al., 2000 K. Paustian, J. Six, E.T. Elliot and H.W. Hunt, Management options for reducing CO2 emissions from agricultural soils, Biogeochemistry 48 (2000), pp. 147-163

Perfect et al., 1990 E. Perfect, B.D. Kay, W.K.P. van Loon, R.W. Sheard and T. Pojasok, Factors influencing soil structural stability within a growing season, Soil Sci. Soc. Am. J. 54 (1990), pp. 173179.

Puget et al., 1995 P. Puget, C. Chenu and J. Balesdent, Total and young organic matter distributions in aggregates of silty cultivated soils, Eur. J. Soil Sci. 46 (1995), pp. 449-459. SAS Institute, 1990 SAS Institute, SAS user's guide: Statistics. 6th Ed. vol. 2, SAS Inst., Cary, NC, USA (1990).

Saber and Mrabet, 2002 N. Saber and R. Mrabet, Impact of no tillage and crop sequence on selected soil quality attributes of a vertic calcixeroll soil in Morocco, Agronomie 22 (2002), pp. 451-459.

Shaver et al., 2002 T.M. Shaver, G.A. Peterson, L.R. Ahuja, D.G. Westfall, L.A. Sherrod and G. Dunn, Surface soil physical properties after twelve years of dryland no-till management, Soil Sci. Soc. Am. J. 66 (2002), pp. 1296-1303.

Shaver et al., 2003 T.M. Shaver, G.A. Peterson and L.A. Sherrod, Cropping intensification in dryland systems improves soil physical properties: regression relations, Geoderma 116 (2003), pp. 149-164.

Singh et al., 1994 B. Singh, D.S. Chanasyk, W.B. McGill and M.P.K. Nyborg, Residue and tillage management effects on soil properties of a typic cryoboroll under continuous barley, Soil Tillage Res. 32 (1994), pp. 117-133. 
Six et al., 1998 J. Six, E.T. Elliot, K. Paustian and J.W. Doran, Aggregation and soil organic matter accumulation in cultivated and native grassland soils, Soil Sci. Soc. Am. J. 62 (1998), pp. 1367-1377. Six et al., 2002 J. Six, C. Feller, K. Denef, S.M. Ogle, J.C. Moraes Sa and A. Albrecht, Soil organic matter, biota and aggregation in temperate and tropicals soils-effects of no-tillage, Agronomie 22 (2002), pp. 755-775.

Six et al., 2004 J. Six, H. Bossuyt, S. Degryze and K. Denef, A history of research on the link between (micro)aggregates, soil biota, and soil organic matter dynamics, Soil Tillage Res. 79 (2004), pp. 7-31. Smettem et al., 1992 K.R.J. Smettem, A.D. Rovira, S.A. Wace, B.R. Wilson and A. Simon, Effect of tillage and crop rotation on the surface stability and chemical properties of a red-brown earth (Alfisol) under wheat, Soil Tillage Res. 22 (1992), pp. 27-40

Soil Survey Staff, 1975 Soil Survey Staff, Soil Taxonomy, a Basic System of Soil Classification for Making and Interpreting Soil Surveys. USDA-SCS Agric. Handbook 436, US Gov. Print. Office, Washington, DC, USA (1975).

Tisdall and Oades, 1982 J.M. Tisdall and J.M. Oades, Organic matter and water-stable aggregates in soils, J. Soil Sci. 33 (1982), pp. 141-163.

Traoré et al., 2000 O. Traoré, V. Groleau-Renaud, S. Plantureux, A. Tubeileh and V. Boeuf-Tremblay, Effect of root mucilage and modelled root exudates on soil structure, Eur. J. Soil Sci. 51 (2000), pp. $575-581$.

Unger and Fulton, 1990 P.W. Unger and L.J. Fulton, Conventional and no-tillage effects on upper root zone soil conditions, Soil Tillage Res. 16 (1990), pp. 337-344.

Vance et al., 1987 E.D. Vance, P.C. Brookes and D.S. Jenkinson, An extraction method for measuring soil microbial biomass C, Soil Biol. Biochem. 19 (1987), pp. 703-707.

Yang and Wander, 1998 X. Yang and M.M. Wander, Temporal changes in dry aggregate size and stability: tillage and crop effects on a silty loam Mollisol in Illinois, Soil Tillage Res. 49 (1998), pp. 173183

Youker and McGuiness, 1957 R.E. Youker and J.L. McGuiness, A short method of obtaining mean weight-diameter values of aggregate analyses of soils, Soil Sci. 83 (1957), pp. 291-294. 
Table 1.

Site and soil properties at the experimental site (López et al., 1998)

\begin{tabular}{|c|c|c|}
\hline \multicolumn{3}{|l|}{ Site and soil characteristics } \\
\hline Mean annual air temperature $\left({ }^{\circ} \mathrm{C}\right)$ & 14.5 & \\
\hline Mean annual precipitation (mm) & 390 & \\
\hline Soil classification ${ }^{\mathrm{a}}$ & Xerollic Calciorthid & \\
\hline Soil depth $(\mathrm{cm})$ & $0-20$ & $20-40$ \\
\hline \multicolumn{3}{|l|}{ Particle size distribution $\left(\mathrm{g} \mathrm{kg}^{-1}\right)$} \\
\hline Sand $(2000<\varnothing<50 \mu \mathrm{m})$ & 293 & 279 \\
\hline Silt $(50<\varnothing<2 \mu \mathrm{m})$ & 484 & 460 \\
\hline Clay $(\varnothing<2 \mu \mathrm{m})$ & 223 & 261 \\
\hline $\mathrm{pH}\left(\mathrm{H}_{2} \mathrm{O}, 1: 2.5\right)$ & 8.3 & 8.3 \\
\hline Electrical conductivity $(1: 5)\left(\mathrm{dS} \mathrm{m}^{-1}\right)$ & 0.25 & 0.28 \\
\hline $\mathrm{CaCO}_{3}\left(\mathrm{~g} \mathrm{~kg}^{-1}\right)$ & 432 & 425 \\
\hline
\end{tabular}

a USDA classification (Soil Survey Staff, 1975). 


\section{Table 2.}

Total monthly precipitation $(P)$ and mean monthly maximum and minimum air temperatures $(T)$ recorded at the experimental site during the 2004-2005 period

\begin{tabular}{|c|c|c|c|c|c|c|}
\hline & \multicolumn{3}{|l|}{2004} & \multicolumn{3}{|l|}{2005} \\
\hline & \multirow{2}{*}{$\begin{array}{l}P \\
(\mathrm{~mm})\end{array}$} & \multicolumn{2}{|c|}{$T\left({ }^{\circ} \mathrm{C}\right)$} & \multirow{2}{*}{\begin{tabular}{|l}
$P$ \\
$(\mathrm{~mm})$
\end{tabular}} & \multicolumn{2}{|c|}{$T\left({ }^{\circ} \mathrm{C}\right)$} \\
\hline & & Max. & Min. & & Max. & Min. \\
\hline January & 10.3 & 12.7 & 3.1 & 2.4 & 7.2 & 0.0 \\
\hline February & 43.4 & 9.8 & 0.5 & 6.9 & 10.4 & -1.7 \\
\hline March & 56.4 & 14.3 & 2.0 & 7.3 & 17.7 & 1.9 \\
\hline April & 42.0 & 17.6 & 4.8 & 15.6 & 20.8 & 6.4 \\
\hline May & 34.9 & 23.3 & 8.7 & 48.5 & 26.4 & 10.7 \\
\hline June & 5.9 & 32.3 & 14.3 & 45.0 & 32.5 & 15.5 \\
\hline July & 14.5 & 32.1 & 15.9 & 0.2 & 33.2 & 16.7 \\
\hline August & 10.5 & 32.3 & 16.7 & 4.0 & 31.3 & 16.0 \\
\hline September & 25.3 & 29.0 & 14.5 & 28.9 & 27.2 & 12.9 \\
\hline October & 32.9 & 23.8 & 10.2 & 46.1 & 21.9 & 10.6 \\
\hline November & 8.5 & 13.1 & 2.9 & 22.4 & 14.3 & 3.9 \\
\hline December & 32.7 & 10.9 & 3.0 & 9.3 & 8.4 & -1.8 \\
\hline
\end{tabular}


Table 3.

Sampling dates and cropping system phases (CC, continuous cropping; CF, barley-fallow rotation)

\begin{tabular}{|l|l|l|}
\hline Sampling date & Cropping system & Cropping system phase \\
\hline 10 February 2004 & CC & Crop growth \\
\hline & CF & Crop growth \\
\hline 4 May 2004 & CC & Crop growth \\
\hline & CF & Crop growth \\
\hline 4 July 2004 & CC & Post-harvest \\
\hline & CF & Post-harvest \\
\hline 6 September 2004 & CC & Fallow \\
\hline & CF & Fallow \\
\hline 22 November 2004 & CC & Sowing \\
\hline & CF & Fallow \\
\hline 8 March 2005 & CC & Crop growth \\
\hline & CF & Fallow \\
\hline 9 May 2005 & CC & Crop growth \\
\hline & CF & Fallow \\
\hline 1 July 2005 & CC & Post-harvest \\
\hline & CF & Fallow \\
\hline & & Fallow \\
\hline & CF & \\
\hline & & Callow \\
\hline & & \\
\hline
\end{tabular}




\section{Table 4.}

Tillage and cropping system effects on mean weight diameter (MWD), water stability of air-dry 1-2 mm size aggregates (WAS ${ }_{A D}$ ) and water stability of field-moist 1-2 mm size aggregates (WAS ${ }_{F M}$ ) at the soil surface (0-5 cm depth) for the whole study period (February 2004 to September 2005)

\begin{tabular}{|c|c|c|c|c|c|}
\hline \multirow[t]{2}{*}{ Aggregate indexes } & \multirow[t]{2}{*}{ Cropping system ${ }^{\mathrm{a}}$} & \multicolumn{4}{|c|}{ Tillage treatment $\underline{\underline{b}}$} \\
\hline & & NT & RT & CT & Mean \\
\hline \multirow[t]{2}{*}{ MWD (mm) } & $\mathrm{CC}$ & $2.85 a \mathrm{~A}^{\mathrm{c}}$ & 2.20b B & $2.31 \mathrm{~b} \mathrm{~A}$ & $2.45 \mathrm{~A}$ \\
\hline & CF & $2.97 a \mathrm{~A}$ & $2.39 \mathrm{~b} \mathrm{~A}$ & $2.28 \mathrm{~b} \mathrm{~A}$ & $2.55 \mathrm{~A}$ \\
\hline \multirow[t]{2}{*}{ WAS $_{A D}(\%)$} & $\mathrm{CC}$ & $43 a A$ & $21 \mathrm{~b} \mathrm{~A}$ & $16 \mathrm{cA}$ & $27 \mathrm{~A}$ \\
\hline & $\mathrm{CF}$ & $18 a \mathrm{~B}$ & $12 c B$ & $15 b A$ & $15 B$ \\
\hline \multirow[t]{2}{*}{ WAS $_{\mathrm{FM}}(\%)$} & $\mathrm{CC}$ & 43a A & $23 b \mathrm{~A}$ & $20 \mathrm{~b} \mathrm{~A}$ & $28 \mathrm{~A}$ \\
\hline & CF & $27 a B$ & $20 b \mathrm{~A}$ & $18 \mathrm{~b} \mathrm{~A}$ & $22 \mathrm{~A}$ \\
\hline
\end{tabular}

${ }^{\text {a }} \mathrm{CC}$, continuous barley cropping; CF, barley-fallow rotation.

${ }^{\mathrm{b}} \mathrm{NT}$, no-tillage; RT, reduced tillage; CT conventional tillage.

${ }^{\mathrm{C}}$ Different lower case letters indicate significant differences among tillage treatments within the same cropping system $(P<0.05)$. Different upper case letters indicate significant differences between cropping systems within the same tillage treatment $(P<0.05)$. 


\section{Table 5.}

Tillage and cropping system effects on total soil organic carbon, 1-2 mm aggregate organic $C$, microbial biomass $C$ and soil water content at the soil surface $(0-5 \mathrm{~cm}$ depth), for the whole study period (February 2004 to September 2005)

\begin{tabular}{|c|c|c|c|c|}
\hline \multirow[t]{2}{*}{ Soil properties } & \multirow[t]{2}{*}{ Cropping system ${ }^{\mathrm{a}}$} & \multicolumn{3}{|c|}{ Tillage treatment ${ }^{\underline{b}}$} \\
\hline & & NT & RT & CT \\
\hline \multirow[t]{2}{*}{ Total soil organic $\mathrm{C}\left(\mathrm{g} \mathrm{kg}^{-1}\right)$} & CC & $13.6 \mathrm{a} \mathrm{A}^{\mathrm{c}}$ & $10.4 \mathrm{~b} \mathrm{~A}$ & $9.0 \mathrm{~b} \mathrm{~A}$ \\
\hline & CF & $11.7 a \mathrm{~B}$ & 9.5ab A & 8.0b A \\
\hline \multirow[t]{2}{*}{$1-2 \mathrm{~mm}$ aggregate organic $\mathrm{C}\left(\mathrm{g} \mathrm{kg}^{-1}\right)$} & CC & $1.32 \mathrm{a} A$ & $0.99 b \mathrm{~A}$ & $0.90 \mathrm{~b} \mathrm{~A}$ \\
\hline & CF & $1.13 a \mathrm{~B}$ & $0.93 \mathrm{~b} \mathrm{~A}$ & $0.87 b \mathrm{~A}$ \\
\hline \multirow[t]{2}{*}{ Microbial biomass $\mathrm{C}\left(\mathrm{mg} \mathrm{kg}^{-1}\right)$} & CC & $443 a \mathrm{~A}$ & $301 b \mathrm{~A}$ & $174 \mathrm{c} \mathrm{A}$ \\
\hline & CF & $314 a$ B & $218 b \mathrm{~A}$ & $137 \mathrm{cA}$ \\
\hline \multirow[t]{2}{*}{ Soil water content $\left(\mathrm{g} \mathrm{g}^{-1}\right)$} & CC & $0.20 \mathrm{a} A$ & $0.19 a \mathrm{~A}$ & $0.20 \mathrm{a} A$ \\
\hline & CF & $0.15 a \mathrm{~A}$ & $0.17 a \mathrm{~A}$ & $0.15 a \mathrm{~A}$ \\
\hline
\end{tabular}

${ }^{a} \mathrm{CC}$, continuous barley cropping; $\mathrm{CF}$, barley-fallow rotation.

${ }^{\mathrm{b}} \mathrm{NT}$, no-tillage; RT, reduced tillage; CT conventional tillage.

${ }^{\mathrm{c}}$ Different lower case letters indicate significant differences among tillage treatments within the same cropping system $(P<0.05)$. Different upper case letters indicate significant differences between cropping systems within the same tillage treatment $(P<0.05)$. 


\section{Table 6.}

Determination coefficients $\left(R^{2}\right)$ between soil properties and aggregation indexes (MWD, mean weight diameter; $W_{A D}$, water aggregate stability of air-dry 1-2 mm size aggregates; $W_{A} S_{F M}$, water aggregate stability of field-moist $1-2 \mathrm{~mm}$ size aggregates)

\begin{tabular}{|c|c|c|c|}
\hline \multirow[t]{2}{*}{ Soil properties } & \multicolumn{3}{|c|}{ Aggregation indexes } \\
\hline & MWD & WAS $_{A D}$ & WAS $_{\mathrm{FM}}$ \\
\hline Total soil organic $\mathrm{C}$ & 0.400 & 0.810 策束 & 0.810 类标 \\
\hline $1-2 \mathrm{~mm}$ aggregate organic $\mathrm{C}$ & 0.620 *⿻一𠃋十 & 0.910 絭絭 & 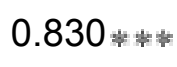 \\
\hline Microbial biomass $\mathrm{C}$ & 0.450 敫 & $0.720 \div * *$ & 0.630 慗零 \\
\hline Soil water content & $0.010 \mathrm{~ns}$ & 0.050 ns & $0.110 \mathrm{~ns}$ \\
\hline
\end{tabular}

${ }^{* * *} P<0.001 ;{ }^{* *} P<0.01 ;$ ns, not significant. 
Fig. 1. Dry aggregate size distribution at the soil surface $(0-5 \mathrm{~cm}$ depth) under three tillage treatments (NT, no-tillage; RT, reduced tillage; CT, conventional tillage) averaged over the whole study period (from February 2004 to September 2005) for continuous barley (CC) and barley-fallow rotation (CF). Different letters above bars indicate significant differences among tillage treatments within the same aggregate size class $(P<0.05)$.
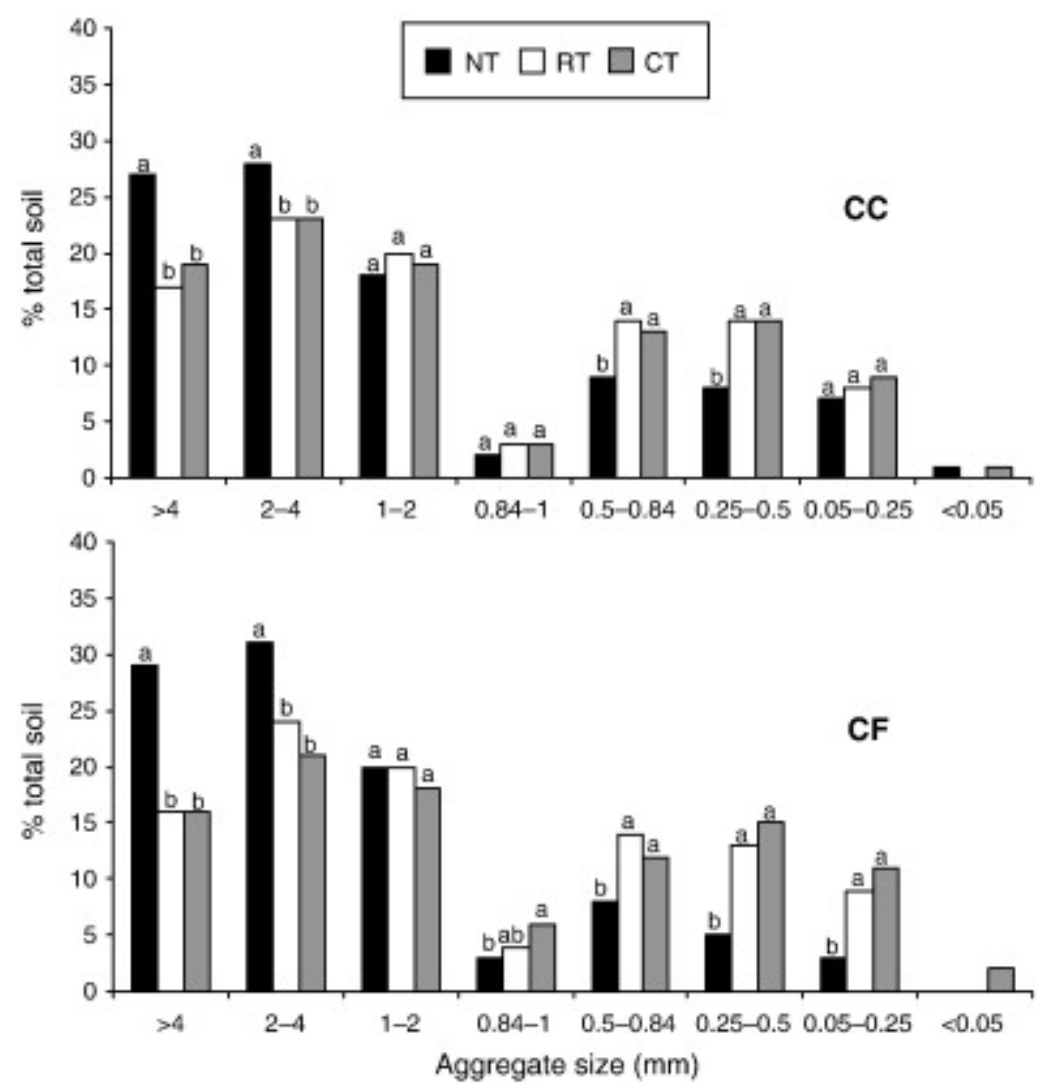


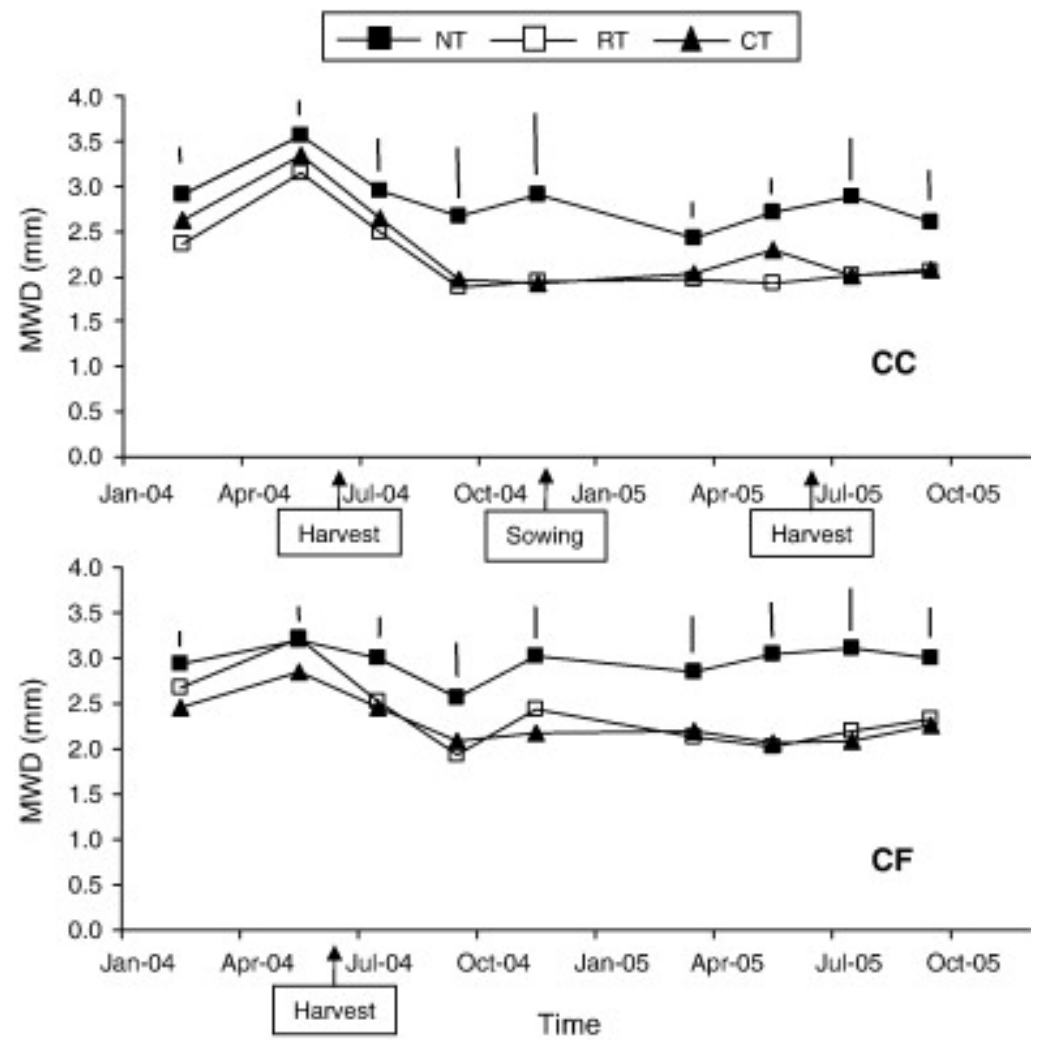

Fig. 2. Temporal variation of the mean weight diameter (MWD) at the soil surface $(0-5 \mathrm{~cm}$ depth) as affected by tillage (NT, no-tillage; RT, reduced tillage; CT, conventional tillage) and cropping system (CC, continuous barley cropping; CF, barley-fallow rotation) over the study period (February 2004 to September 2005). Bars indicate LSD $(P<0.05)$ for comparisons among tillage treatments at the same date where significant differences were found. 


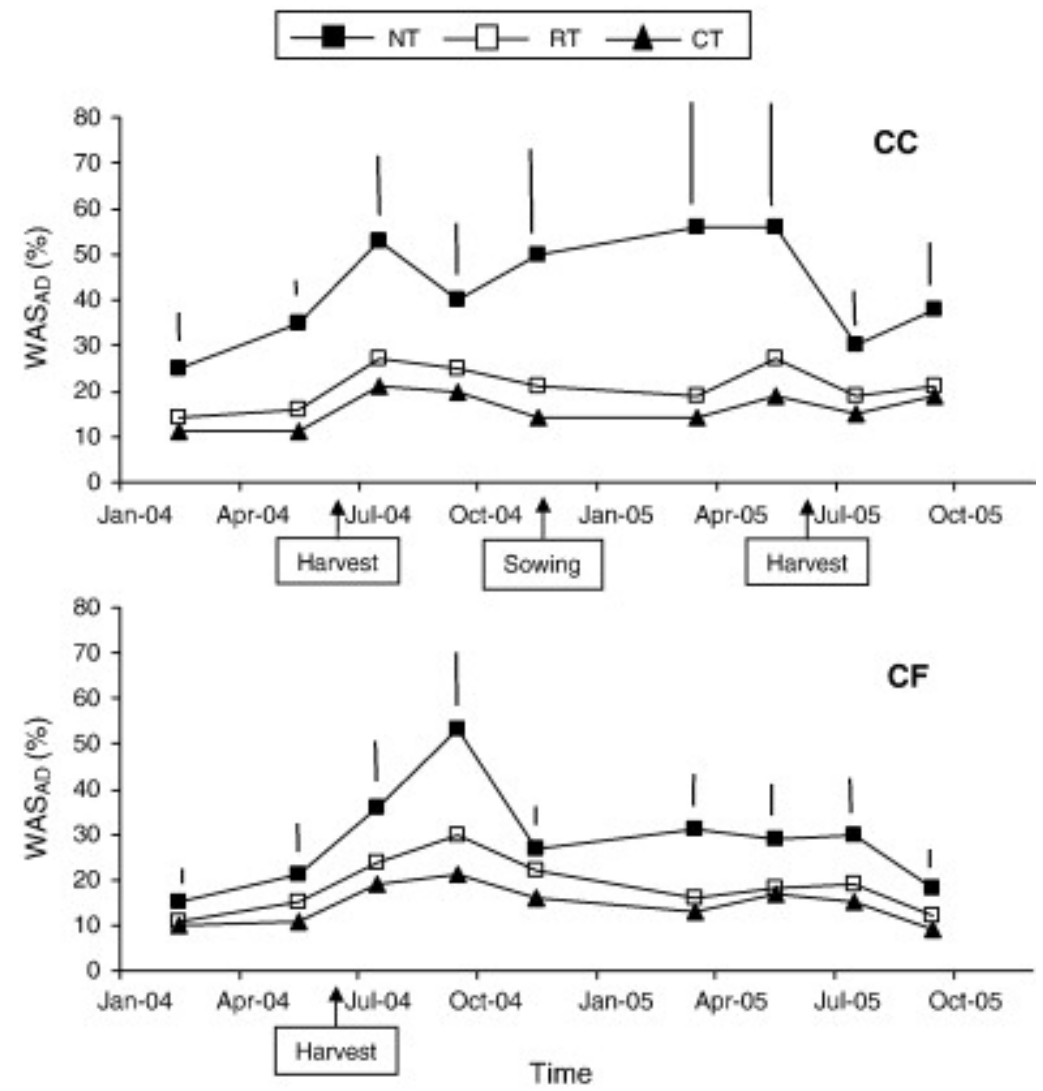

Fig. 3. Temporal variation of water stability of air-dried 1-2 $\mathrm{mm}$ size aggregates $\left(W A S_{A D}\right)$ at the soil surface (0-5 cm depth) as affected by tillage (NT, no-tillage; RT, reduced tillage; CT, conventional tillage) and cropping system (CC, continuous cropping; $\mathrm{CF}$, barley-fallow rotation), over the study period (from February 2004 to September 2005). Bars indicate LSD $(P<0.05)$ for comparison among tillage treatments at the same date where significant differences were found. 
Fig. 4. Variation of gravimetric soil water content at the soil surface $(0-5 \mathrm{~cm}$ depth) as affected by tillage (NT, no-tillage; RT, reduced tillage; CT, conventional tillage) and cropping system (CC, continuous barley cropping; CF, barley-fallow rotation) over the study period (February 2004 to September 2005). Bars indicate LSD $(P<0.05)$ for comparison among tillage treatments at the same date where significant differences were found.

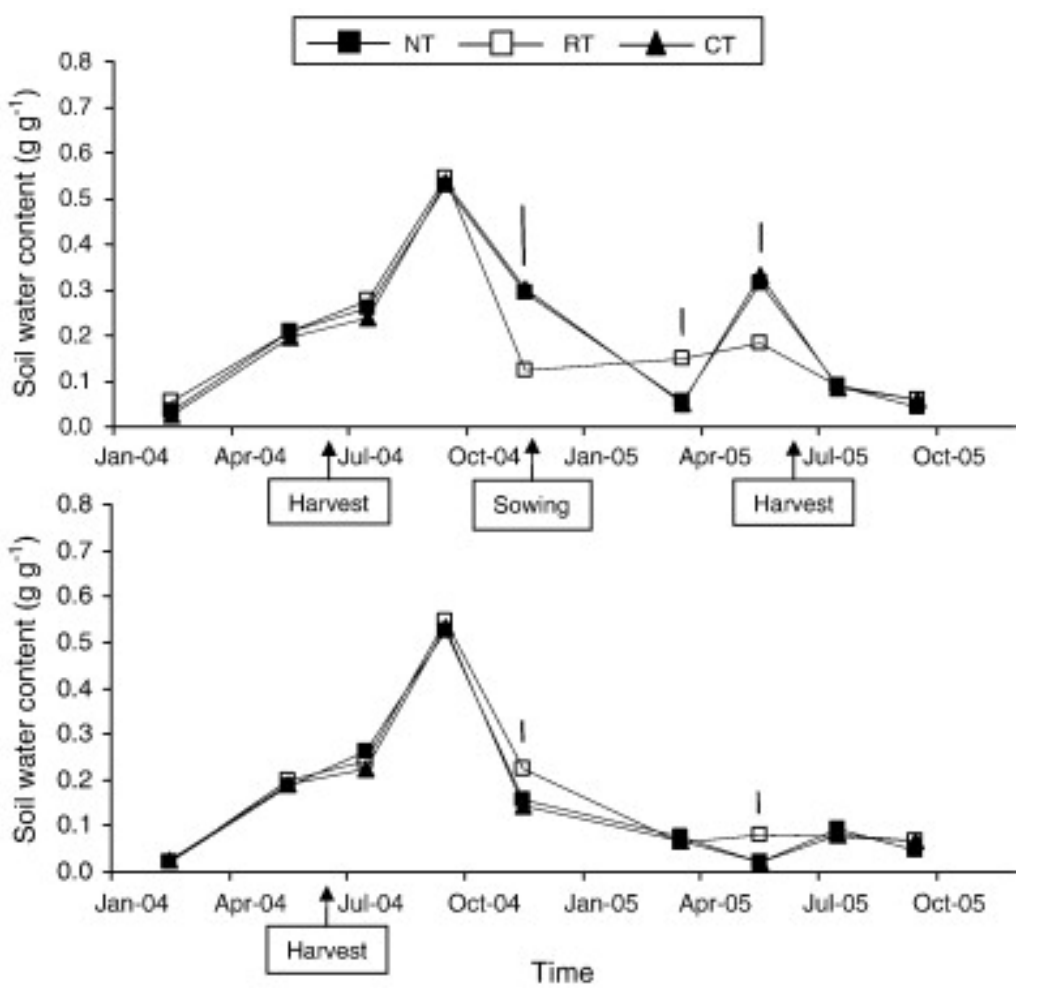


Fig. 5. Temporal variation of water stability of field-moist $1-2 \mathrm{~mm}$ size aggregates $\left(\mathrm{WAS} \mathrm{F}_{\mathrm{FM}}\right)$ at the soil surface (0-5 cm depth) as affected by tillage (NT, no-tillage; RT, reduced tillage; CT, conventional tillage) and cropping system (CC, continuous cropping; $\mathrm{CF}$, barley-fallow rotation), over the study period (from February 2004 to September 2005). Bars indicate LSD $(P<0.05)$ for comparison among tillage treatments at the same date where significant differences were found.
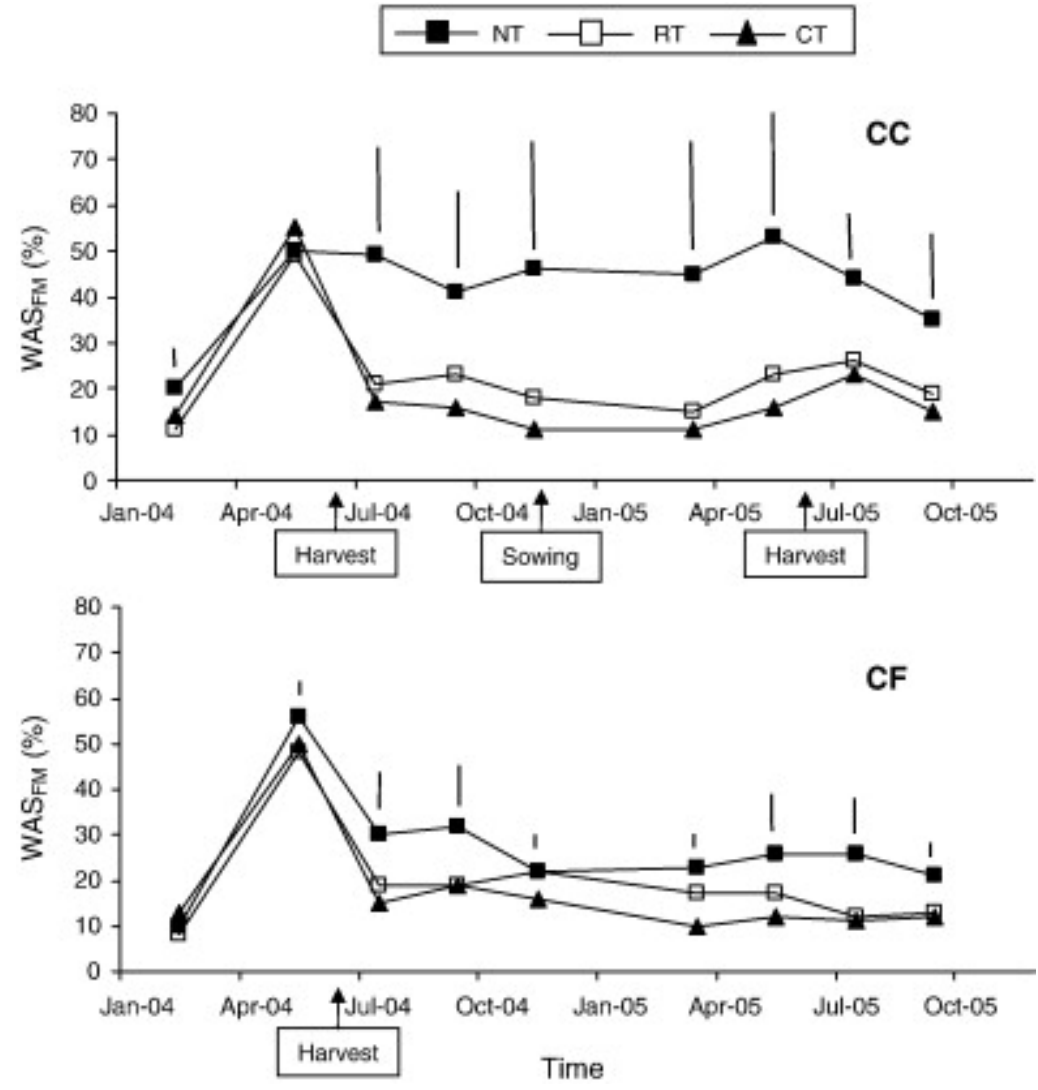